\title{
ІСТОРІЯ УКРАЇНСЬКОЇ ПУНКТУАЦІї
}

\author{
ІРИНА КОЧАН \\ Львівський національний університет імені Івана Франка, Львів - Україна \\ kim1950@i.ua; ORCID: 0000-0002-5709-2933 \\ HISTORIA UKRAIŃSKIEJ INTERPUNKCJI \\ IRYNA KOCZAN \\ Lwowski Uniwersytet Narodowy imienia Iwana Franki, Lwów - Ukraina
}

\begin{abstract}
STRESZCZENIE. W artykule omówiono główne etapy rozwoju i kształtowania się interpunkcji w języku ukraińskim. Ekskurs historyczny pozwolił określić zarówno tendencje wspólne w systemie znaków interpunkcyjnych, jak i odrębne, charakterystyczne dla narodowej tradycji naukowej. Umożliwił on również prześledzenie procesu włączania znaków interpunkcyjnych do pisowni języka ukraińskiego.
\end{abstract}

Słowa kluczowe: język ukraiński, interpunkcja, historia, gramatyka, pisownia.

\section{HISTORY OF UKRAINIAN PUNCTUATION \\ IRYNA KOCHAN \\ Ivan Franko National University, Lviv — Ukraine}

ABSTRACT. The main milestones of the development and establishing the punctuation in the Ukrainian language are being discovered in the article. A historical excursion allowed to outline both common tendencies and actual national approaches to the implementation of a system of the punctuation marks, to show their introduction into the spelling system of the Ukrainian language.

Key words: Ukrainian language, punctuation, history, grammar, spelling.

Пермін “пунктуація” походить від латинського “рuncium”, що в перекладі означає “крапка”. Його вживають у двох значеннях: “1) правила розстановки розділових знаків; 2) самі розділові знаки”. Розділові знаки - це та частина графічної системи мови, основне призначення якої - полегшити розуміння тексту. Цей розділ правопису привертав до себе увагу багатьох учених. Однак і на сьогодні він залишається ще малодослідженим. Аналізу проблеми вживання розділових знаків у писемних пам'ятках та стародруках торкалися В. Ващенко ${ }^{1}$, В. Німчук ${ }^{2}$, М. Пещак ${ }^{3}$, історії їхнього виникнення - Н. Андрощук ${ }^{4}$,

${ }^{1}$ В. Ващенко, Граматика Мелетія Смотрицького, [в:] „Українська мова в школі”, 1957, № 3 , c. 27-33.

${ }^{2}$ В. Німчук, Граматика М. Смотрицького - перлина давнього мовознавства, [в:] Електронний ресурс: http//litopys/org.ua/smotrgram/sm01.htm; В. Німчук, Систематичний підручник иерковнослов'янської мови „Граматика словенская” Л. Зизанія, [в:] Електронний ресурс: http// litopys/org.ua/smotrgram/sm01.htm (12.02.2018).

${ }^{3}$ М. Пещак, Формальні ознаки членування тексту грамот, [в:] Її ж, Стиль ділових документів XIV cm. (структура тексту), Київ 1979, с. 65-79.

${ }^{4} \mathrm{H}$. Андрощук, Формування пунктуачійної системи сучасної украӥнської мови та ї̈ відображення в правописних джерелах, [в:] „Науковий вісник Східноєвропейського національного університету імені Лесі Українки. Філологічні науки. Мовознавство”, Луцьк 2013, вип. 22, с. 3. 
Л. Булаховський 5 Н. Гуйванюк ${ }^{6}$, А. Загнітко ${ }^{7}$, О. Огієнко ${ }^{8}$, I. Савченко9. Художні функції та стилістичне використання пунктограм були предметом зацікавлення О. Бандури ${ }^{10}$, В. Ващенка ${ }^{11}$, А. Загнітка ${ }^{12}$. Особливості становлення пунктуаційної термінології досліджували Н. Москаленко ${ }^{13}$, I. Огієнко ${ }^{14}$, принципи української пунктуації та правила уживання розділових знаків в українській мові були в полі зору Л. Булаховського, А. Бурячка ${ }^{15}$, Н. Гуйванюк ${ }^{16}$ Н. Мозгової ${ }^{17}$, К. Шульжука ${ }^{18}$ тощо.

Мета цієї статті - узагальнивши вищеназвані здобутки, ознайомити читача $з$ основними віхами появи розділових знаків, їхнього удосконалення, впровадження в правописну систему української мови.

Перші свідчення про вживання розділових знаків відносять до $\mathrm{V}$ ст. до н. е. Так, драматург Еврипід позначав на зміну мовця в діалогах гостроконечним знаком, що походить від лямбди $<$ ), філософ Платон інколи закінчував розділи своїх книжок знаком, що нагадує сучасну двокрапку.

Поява першого розділового знака пов'язана з ім'ям Apicmoтеля, що жив у $1 \mathrm{~V}$ ст. до н. е. Це був параграфос — коротка горизонтальна риска знизу біля початку рядка. Його уживали, щоб указати на зміну смислового значення, i, відповідно, на новий достатньо великий за обсягом розділ тексту. Цей самий мудрець винайшов систему трьох крапок: крапка знизу — кома, яку ставили в кінці короткого відрізку мовлення; крапка згори - nеріодос - ділила текст на більші відрізки, а крапка посередині - колон - на середні.

Батьком пунктуації Олександрійської доби вважають грецького математика Арістофана Візантійського (260-180 до н. е.), що впорядкував першу систему розділових знаків, до якої входили три знаки: distinctio - крапка вгорі, distinctio media - крапка посередині рядка i subdistinctio - крапка внизу рядка, підкреслюючи їхне інтонаційне навантаження та смислову функцію. Різниця між нижньою, середньою та верхньою крапками із часом стала нечіткою, поки не залишилися всього одна крапка, яку розташовували в будь-якому місці рядка для позначення паузи - суміш коми, двокрапки й крапки ${ }^{19}$.

${ }_{5}^{5}$ Л. Булаховський, Украӥнська пунктуачія, Київ 1947.

${ }^{6}$ Н. Гуйванюк, Історична змінність пунктуаиії та зміни в українській пунктуації, [в:] Ï̈̈ ж, Сучасні проблеми мовознавства та літературознавства, Чернівці 2002, вип. 6, с. 299-305. 2000.

7 А. Загнітко, Теоретична граматика сучасної украйнської мови. Синтаксис, Донецьк

${ }^{8}$ І. Огієнко, Нариси з історії украӥнської мови: система украӥнського правопису, Варшава 1927.

${ }^{9}$ I. Савченко, Історичний шлях украӥнської пунктуаційної системи, [в:] „Мовознавчий вісник”, зб. наук. праць, Черкаси 2011, вип. 12-13, с. 284-291.

${ }^{10}$ О. Бандура, Художні функиії поетичної пунктуаиїі, [в:] „Українська мова та літератуpa", 1997, № 46 (62), с. 12.

${ }^{11}$ В. Ващенко, Стилістичне використання пунктуації, [в:] „Українська мова в школі”, 1951, № 5, c. 31-35.

12 А. Загнітко, Теоретична граматика ...

${ }^{13}$ Н. Москаленко, Нарис історії украӥнської пунктуаційної термінологї̈, Одеса 1959.

${ }^{14}$ I. Огієнко, Нариси з історії украйнської мови ..., с. 200.

${ }^{15}$ А. Бурячок, Що змінилося в „, Українському правописі”, Київ 1997.

${ }^{16}$ Н. Гуйванюк, Новітні тенденції в украӥнській пунктуації та проблеми авторської пунктуачії. Слово. Речення. Текст, Чернівці 2009, с. 299-305.

${ }^{17} \mathrm{H}$. Мозгова, Синтаксичні принципи правопису та його реалізація, [в:] Електронний pecypc: http:www.donduet.edu.ua/docs/vestnik/2006/Vest_gum__2(30)_2006/SPM/mozgova.doc (14.02.2018).

${ }^{18}$ К. Шульжук, Синтаксис украӥнської мови, Київ 2004.

19 I. Савченко, Історичний шлях ..., с. 284. 
Уважають, що саме Аpicтофан винайшов більшість пунктуаційних знаків, напр., дефіс для написання складних слів, похилу риску, яку ставили біля слів 3 нечітким значенням. Саме Арістофан уперше почав використовувати знак наголосу (названий діакритичний знак помилково відносили до системи розділових знаків, і ця традиція в деяких мовах трималася до поч. XX ст.). Однак ці знаки не знайшли поширення, їх використовували спорадично й безсистемно.

Арістофанова пунктуаційна система 3 невеликими змінами була сприйнята римлянами й дожила аж до часу Карла Великого (768-814 pp. н. е.), коли латинське письмо запровадило досконалішу систему розділових знаків.

Трохи пізніше (VII ст.) Ісидор Севільський описав оновлену версію системи Арістофана. Він переставив крапки за висотою відповідно до довжини паузи, яку вони позначали. Більше за те, Ісидор першим пов'язав пунктуацію зі змістом тексту. "Нижня" крапка, яка отримала назву subdistinctio, позначала не просто паузу. Ї̈̈ почали ставити за граматичними правилами, що дуже нагадували використання сучасної коми. У той час як “верхню” крапку, або distinctio finalis, почали ставити наприкінці речення.

Незабаром після цього між словами з'явилися пропуски - винахід ірландських і шотландських ченців, які втомилися розплутувати незнайомі латинські слова.

Із грецькою традицією вживання графічних знаків членування письма тісно пов'язана пунктуація слов'янського, зокрема руського, письма. Слов'яно-грецькі контакти мають дуже давню історію. Культурного впливу з боку Стародавньої Греції зазнавала Скіфія впродовж VI-IV ст. до н. е. Ї̈̈ територію заселяли в той час праслов'янські протоукраїнські племена. Культурне й торговельне піднесення давніх нащадків періоду черняхівської культури (III-IV ст. н. е.) сприяло поширенню грецького й латинського літерно-звукового письма. Під час розкопок на уламках черняхівського посуду виявлено написи із грецьких та латинських літер. У V-VI ст. (у добу Великого переселення народів) слов'яни заселяли Наддніпрянщину й проникли на Балкани, ставши безпосередніми сусідами візантійців, що допомагало налагодженню культурно-торговельних зв'язків з Візантією ${ }^{20}$.

Упродовж VI-VII ст. у період утворення східнослов'янських племен, напередодні формування Київської Русі, виникла потреба в писемності. На IX ст. (863р.) припала велика подія - удосконалення солунськими братами-місіонерами Кирилом і Мефодієм слов'янського письма, в основу якого було покладено грецький устав. Із давнім уставом слов'яни успадкували традиції грецької пунктуації й перенесли їх у свої рукописні твори.

У час зародження слов'янської писемності грецькі рукописи IX-X ст. зазвичай використовували крапки внизу, посередині й угорі рядка, двокрапку в значенні крапки чи крапки із комою. Кінець уривка чи якоїсь закінченої частини позначали грубою крапкою (•), хрестиком $(+)$, чотирма крапками (...), трьома крапками (:.) та складеними знаками типу $(. . .-)$ чи $(:-)$ тощо ${ }^{21}$.

Автором нової системи вважають найславетнішого вченого VII ст. Алкуїна (735-804 pp.), англійця за походженням. Алкуїн додав кілька нових знаків. Саме він увів в обіг punktum (.) - кому і puktum versus (;) - крапку із комою для позначення пауз та змін інтонації. Він уживав перетинку (кому) у сполученні із крапкою - однією чи двома (; або ..), знак оклику і знак питання (графічні

${ }^{20}$ І. Огієнко, Нариси з історії украӥнської мови ..., с. 199.

${ }^{21}$ Там само. 
накреслення двох останніх знаків відрізнялися від сучасного) ${ }^{22}$. Але, незважаючи на часте використання, статусу знаків системності в уживанні вони так й не досягли. Саме ця система була запозичена, на думку I. Огієнка, українськими рукописами. „Крапку ставили в Богослужбових Книжках як вказівку при читанні чи співанні в Церкві. Мало не кожен давній наш рукопис знає ... свою осібну систему знаків розділових"23.

Грецькі рукописи IX-X ст. в кінці абзацу (великої частини тексту) ставили велику крапку (.), хрестик (+), чотири крапки (..), чотири крапки з гачком (..-) або дві крапки з тире (:-).

Слов'янське письмо запозичило й собі від греків ці знаки, які ділили текст на частини. Їх можна простежити в літописах IX ст. і в писемних пам'ятках XVI ст. А після XVI ст. українські друковані книжки користуються альдинською системою знаків, яку розробив венеціанський видавець, засновник найкращої на той час друкарні Альд Мануцій Старший. Його книжки так і називалися альдини ${ }^{24}$.

У XII ст. італійський письменник Бонкомпаньйо да Сінья запропонував радикально нову систему пунктуації, що складалася лише з двох знаків: похилої риски (/) - для паузи й тире (-) на позначення кінця речення.

У грамотах XIV ст. зафіксовані такі розділові знаки: одинарна крапка, вертикальна й горизонтальна риска, кілька крапок, різної форми крючки ${ }^{25}$.

Активно почала розвиватися пунктуація від початку книгодрукування. Нову систему розділових знаків, що пізніше поширилася по всій Європі, започаткували італійські типографи в сер. XV ст.

Лише в XV ст. венеціанський друкар Альд Мануцій став уводити в друковані книги знаки пауз - вдих, зміна інтонації, та найбільш уживаними стали кома, крапка 3 комою та двокрапка. У нього також знаходимо крапку, знак питання, дужки, креску він замінив на кому, розмежував велику крапку й малу, уживаючи після першої велику літеру, а після другої - малу. У XVI ст. у праці Orthographiae ratio, яку написав 19-річний Мануиій (один з продовжувачів династії) була подана система розділових знаків (крапка, кома, крапка із комою, двокрапка, дужки, знак питання), що запанувала в Свропі аж до XVIII ст. ${ }^{26}$.

У слов'янських типографіях венеціанська система пунктуації освоюється повільно, поступово. У Львівському виданні Апостола (1574) І. Федорович використав лише крапку й кому, в Острозькій Біблії (1580) послугувався трьома знаками - крапкою, комою й крапкою 3 комою ${ }^{27}$.

Наприкінці XVI ст. та впродовж XVII ст. пунктуаційна система збагачується, завдяки появі Граматики словенської Лаврентія Зизанія (1596), Грамматіки славенския правильное синтагма Мелетія Смотрицького (1691), Лексикона словеноросского Памви Беринди (1627).

В окремому параграфі другого розділу “О точках" Лаврентій Зизаній говорить про 6 розділових знаків: кома, двокрапка, підстильна (крапка з комою), з'єднувальна (-дефіс) і крапка. I наводить приклади їхнього вживання. В основі цих знаків Зизаній поклав смисловий принцип: закінченість чи незакінченість висловлювання. Крапку ставили в кінці закінченого цілого. Інші знаки - кому

\footnotetext{
${ }^{22}$ Там само.

23 Там само, с. 200.

${ }^{24}$ Там само, с. 199.

${ }^{25}$ Н. Андрощук, Формування пунктуаиійной системи ..., с. 3.

${ }^{26}$ I. Огієнко, Нариси з історії украӥнської мови..., с 200.

${ }^{27}$ I. Савченко, Історичний шлях..., с. 286.
} 
і крапку із комою - уживали в середині речення для відокремлення. Підстолія - знак для позначення питальної інтонації, з'єднувальна - знак для позначення переносу слів. Заслуга Л. Зизанія в тому, що він намагався визначити місце кожного знака в тексті.

Автор граматики церковнослов'янської мови М. Смотрицький, напр., використовував десятисчленну знакову систему: крапку посередині і внизу рядка, кому, креску у функції сучасної коми, двокрапку при перерахуванні та у функції сучасної крапки із комою, крапку із комою у функції знака питання й сучасної двокрапки, дужки для виділення вставлених конструкцій. В основі розділових знаків у Смотрицького лежить інтонаційний принцип. Так, риска - це короткий відпочинок при читанні, кома дає змогу читачу зробити більш тривалу паузу, двокрапку вживає в разі, коли думка висловлена не вся, а лише їі частина, однак частини речення більш самостійні, ніж при розділенні комою. Крапку ставить у кінці закінченого виловлювання, знак питання - у кінці питального висловлювання, роз'ємна та з'єднувальна - знаки переносу. Вони позначалися термінами: чортка (/) для позначення невеликої паузи, запятая, двоточка, точка, разнатная (для розділення двох слів), єдинитная (знак переносу) вопросная, удивная, квадратні дужки (чуже висловлювання), круглі дужки (вставні слова) $)^{28}$.

У творчій спадщині Климентія Зіновієва, приблизно датованій періодом між 1700 і 1708 рр., знаходимо традиційні для к. XVII - поч. XVIII ст. розділові знаки: крапку, кому, крапку із комою, двокрапку, крапки. Популярна в його творчому доробку двокрапка, по суті, є універсальним знаком, оскільки ііі використано для відокремлення другорядних членів речення, ужито між частинами складних речень, перед однорідними членами без узагальнювальних слів та $з$ ними, для виділення звертань, у функції сучасної крапки із комою тощо.

Так, книжки й рукописи XVII ст. уже фіксують крапку, двокрапку, кому, крапку із комою, знак питання та знак оклику, дужки, лапки; тоді ж з'являються тире й крапки.

У Кобзарі (1840) — дев'ятичленна система розділових знаків (крапка, знак питання, знак оклику, кома, крапка із комою, двокрапка, тире, дужки, крапки), що цілком відповідало пунктуаційним системам, які були представлені у відомих російських граматиках (збірка поезій вийшла у світ з Санкт-Петербурзької типографіi), ще раз засвідчивши спадкоємність пунктуаційних традицій в українській мові.

У XIX ст. пунктуаційна система найповніше була представлена в Граматиці руської мови С. Смаль-Стоцького і Ф. Гартнера. У ній зазначалося, що основна функція пунктуаційних знаків полягає в тому, щоб „зазначити границі поодиноких речень - головних і побічних...”. У цій навчальній книзі є такі знаки: кропка, питайник, окличник, запинка, середник, двокрапка, павза (-), скобки, знаки наведення (лапки $)^{29}$.

У галицько-українських граматиках XIX ст. окремий розділ з пунктуації відсутній, хоча питання вжитку розділових знаків розглядали спорадично (граматики М. Бутовського (1809), І. Могильницького (1823), А. Могильницького (1829), М. Лучкая (1830), І. Лаврівського (1831), П. Паславського (1832), Й. Лозинського (1846). У граматиках А. Кримського $(1907)^{30}$, С. Тимченка $(1907)^{31}$,

${ }^{28}$ В. Ващенко, Граматика Мелетія Смотрицького ...

${ }^{29}$ С. Смаль-Стоцький, Ф. Гартнер, Граматика руської мови, Відень 1914, с. 168.

${ }^{30}$ А. Крымский, Украинская грамматика для учеников высших классов гимназий и семинарий Приднепровья, Москва 1907, т. 2, вып. 1.

${ }^{31}$ Є. Тимченко, Українська граматика, Київ 1907. 
I. Нечуя-Левицького (1913) ${ }^{32}$ вже більше уваги приділено коментарям уживання розділових знаків, але немає розгорнутого теоретичного коментування принципів пунктуації.

Повністю відсутній розділ про пунктуацію і навіть побіжні зауваження про вжиток розділових знаків і в працях С. Смеречинського, О. Курило, М. Гаєвського, О. Синявського, М. Сулими, не вводить питання пунктуації й І. НечуйЛевицький у другу частину своєї граматики (1914), а пише лише про іiї послідовне відображення в особливостях літературної практики. Це була данина тим загальним устремлінням, що мали місце в лінгвістичній науці поч. XX ст. ${ }^{33}$.

Однією з перших спроб теоретично обгрунтувати пунктуацію в українському мовознавстві була граматика В. Сімовича ${ }^{34}$, що вирізнялася на загальному тлі високим рівнем узагальнення і всеохоплювальним аспектом, оскільки автор включив до граматики як додаток теорію віршування 3 послідовним аналізом усіх його елементів. Аналіз ужитку розділових знаків В. Сімович подає в розділі "Речення". У нього знаходимо 8 розділових знаків: точка, запинка, середник, двоточка, питайник, викличник, пружка, точки, дужки, наводові знаки (лапки), розділка. Про значущість розділових знаків автор писав: „Коли ми хочемо, щоб нас добре розуміли, то в живій мові добираємо все відповідного голосу: то підносимо його, то понижуємо, то вриваємо на якомусь слові, то спиняємося довий час, то знов балакаємо, зовсім не спиняючись і т. д." 35 .

Подібне спостерігаємо і в окресленні назв розділових знаків, яким у кожному випадку подано етимологію: 1) точка (.), звана ще подекуди крапкою; 2) запинка (,), або із грецької: кома; 3) середник, або точка із запинкою (;); 4) двоточка (:), або двокрапка; 5) питайник (?); 6) викличник (!); 7) пружка (-), чужа назва: павза; 8) точки (...); 9) наводові знаки («»), або лапки; 10) дужки () й 11) розділка (-). Під час характеристики розділових знаків та їхньої значущості подається перелік загальних правил їхнього вжитку та винятки, що функційно вагомими в писемному мовленні.

Найголовніші правила украӥнського правопису (1921), укладені Правописною комісією в складі професорів А. Кримського, I. Огієнка та С. Тимченка, не задовольнили рівень вимог мовної практики, оскільки орфографія мала дуже стислий виклад (усього 46 правил), а пунктуації не було розглянуто зовсім ${ }^{36}$. У 1925 р. питання внормування правопису було порушено знову. Його впорядкуванням займалася мовознавча еліта: В. Ганцов, М. Грунський, А. Кримський, О. Курило, О. Синявський, М. Сулима, Є. Тимченко та ін. (понад 50 осіб). Підкомісією, яка редагувала правила пунктуації, керував О. Синявський.

Уперше виходять 3 друку монографії, присвячені українській пунктуації: М. Грунський, М. Мироненко Розділові знаки (1930) $)^{37}$, I. Неутрієвський Найголовнімі правила пунктуації в украӥнській мові. Розділові знаки $(1930)^{38}$, В. Кур-

\footnotetext{
${ }^{32}$ I. Нечуй- Левицький, Граматика украйнської мови, ч. 2, Синтаксис, Київ 1914.

33 Ю. Шевельов, Українська мова в першій половині ХХ cm. (1900-1941): Стан і статус, Чернівці 1993, с. 11.

${ }^{34}$ В. Сімович, Граматика украӥнської мови. Для самонавчання та в допомогу шкільній науці, 2-е вид. з одмінами й додатками, Київ-Ляйпціг 1921, с. 448.

${ }^{35}$ Там само.

${ }^{36}$ В. Німчук, Н. Пуряєва, Iсторія украӥнського правопису: XVI-XX століття, хрестоматія, Київ 2004.

${ }^{37}$ М. Грунський, М. Мироненко, Розділові знаки, Харків 1930.

${ }^{38}$ I. Неутрієвський, Найголовніші правила пунктуації в украӥнській мові. Розділові зна$\kappa и$, Харків 1930.
} 
диновський Розділові знаки в украйнській мові (1931) ${ }^{39}$. Праці цього періоду містять цінний фактичний матеріал, який дав значний поштовх для теоретичних засад синтаксису та пунктуації, а також сприяли засвоєнню практичних навиків, незважаючи на дискусійні позиції. Виходять українські правописи, що фіксують й основні правила української пунктуації, їхнє формування відбувається на синтаксичній основі ${ }^{40}$.

У всіх українських правописах та їхніх перевиданнях правила вживання пунктуаційних знаків здобули собі право на життя, а в граматиках про кодифіковані правила мова не велася й не ведеться, згадується про них принагідно. Це переважно спостерігається тоді, коли значущість розділового знака є вирішальною, оскільки він репрезентує відповідний тип інтонації, що в окремих синтаксичних конструкціях кваліфікується як компенсатор відсутніх (формально не виражених) засобів зв'язку, порівн. безсполучникові складні речення та ін.

У сучасних правописних і граматичних студіях розбіжності в термінології наявні тільки щодо окремих графічних знаків, порівн.: тире - розділка (Д. Кислиця, П. Ковалів); крапка із комою - середник (Д. Кислиця $\left.{ }^{41}\right)$; дефіс - розділка (П. Ковалів) (Український правопис $(960)^{42}$; Український правопис $(1993)^{43}$; Ковалів (1977) $)^{44}$; Кислиця $(1990)^{45}$; Чорній $(1969)^{46}$; Загнітко $\left.(1994)^{47}\right)$. В усіх інших випадках щодо термінологічного окреслення та основних правил вживання розділових знаків у переважній більшості посібників спостерігається тотожність.

В українській мові розділові знаки становлять усталену систему. У ній розрізняють одиничні (. : . ., ; - ? !) і парні розділові знаки (дві коми, два тире, дужки, лапки). Розділові знаки або відділяють частину тексту одну від одної, або виділяють певні відрізки в середині частини. Залежно від цього розділові знаки поділяють на роздільні (у науковій літературі ще вживаються терміни “видільні”, “відокремлювальні”) (іх вісім) та видільні (інший термін — “віддільні”) (дужки і лапки). Перші слугують для розмежування попереднього й наступного речень, частин у складному реченні та однорідних членів речення. До них відносяться крапка, знак питання, знак оклику, три крапки, двокрапка, крапка із комою, абзац. (. ? ! , ; - : ...). Віддільні розділові знаки вживають для позначення меж таких синтаксичних конструкцій, які вставляються в речення з метою доповнення, пояснення, розкриття змісту одного чи кількох членів речення або й речення загалом, тобто ними виділяють звертання, вставні, вставлені компоненти, відокремлені члени речення, пряму мову. До них належать парні розділові знаки: подвійна кома, подвійне тире, дужки, лапки.

Отже, українська пунктуація під впливом західноєвропейської пунктуаційної системи до XVIII ст. в основному сформувалася. Наступне вдосконалення iï пов'язане з розвитком жанрів у XIX ст., а також завдяки художній практиці письменників і діяльності мовознавців-нормалізаторів XX - поч. XXI ст.

\footnotetext{
${ }^{39}$ В. Курдиновський, Розділові знаки в украӥнській мові, Харків 1931.

${ }^{40}$ А. Загнітко, Теоретична граматика ...

${ }^{41}$ Д. Кислиця, Граматика украӥнської мови, ч. 2, Синтакса, Нью-Йорк 1990.

${ }^{42}$ Украӥнський правопис, Київ 1960.

${ }^{43}$ Украӥнський правопис, Кийв 1993.

${ }^{44}$ П. Ковалів, Украйнський правопис і вимова, Нью-Йорк 1946; П. Ковалів, Украйнський правопис і вимова, Нью-Йорк 1977.

${ }^{45}$ Д. Кислиця, зазнач. джер.

${ }^{46}$ С. Чорній, Граматика украӥнської мови, ч. 2, Синтакса, Брокпорт; Нью-Йорк 1969.

${ }^{47}$ А. Загнітко, Сучасна украӥнська літературна мова. Синтаксис простого ускладненого і складного речення, Донецьк 1994.
} 
I. Кочан

\section{Список використаної літератури}

Андрощук Н., Формування пунктуачійної системи сучасної украӥнської мови та ії відображення в правописних джерелах, [в:] „Науковий вісник Східноєвропейського національного університету імені Лесі Українки. Філологічні науки. Мовознавство", Луцьк 2013, вип. 22, с. 3-7.

Бандура О., Художні функиії поетичної пунктуачї, [в:] „Українська мова та літератуpa”, 1997, № 46 (62), с. 9-12.

Булаховський Л., Українська пунктуачія, Київ 1947.

Бурячок А., Що змінилося в „Українському правописі”, Київ 1997.

Ващенко В., Граматика Мелетія Смотрицького, [в:] „Українська мова в школі”, 1957, № 3, c. 27-33.

Ващенко В., Стилістичне використання пунктуачії, [в:] „Українська мова в школі”, 1951, № 5, c. 31-35.

Грунський М., Мироненко М., Розділові знаки, Харків 1930.

Гуйванюк Н., Історична змінність пунктуачії та зміни в украӥнській пунктуації, [в:] Її ж, Сучасні проблели мовознавства та літературознавства, Чернівці 2002, вип. 6, с. 299-305.

Гуйванюк Н., Новітні тендениії в українській пунктуації та проблеми авторської пунктуації. Слово. Речення. Текст, Чернівці 2009, с. 486-492.

Загнітко А., Сучасна українська літературна мова. Синтаксис простого ускладненого і складного речення, Донецьк 1994.

Загнітко А., Теоретична граматика сучасної украӥнської мови. Синтаксис, Донецьк 2000.

Кислиця Д., Граматика украӥнської мови, ч. 2, Синтакса, Нью-Йорк 1990.

Ковалів П., Украӥнський правопис і вимова, Нью-Йорк 1946.

Ковалів П., Украӥнський правопис і вимова, Нью-Йорк 1977.

Крымский А., Украинская грамматика для учеников высших классов гимназий и семинарий Приднепровья, Москва 1907, т. 2, вып. 1.

Курдиновський В., Розділові знаки в українській мові, Харків 1931.

Мозгова Н., Синтаксичні принщипи правопису та його реалізащія, [в:] Електронний pecypc: http:www.donduet.edu.ua/docs/vestnik/2006/Vest_gum__2(30)_2006/SPM/ mozgova.doc (14.02.2018).

Москаленко Н., Нарис історії української пунктуаційної термінологї, Одеса 1959.

Неутрієвський І., Найголовніші правила пунктуачії в українській мові. Розділові знаки, Харків 1930.

Нечуй-Левицький І., Граматика украӥнської мови, ч. 2, Синтаксис, Київ 1914.

Німчук В., Граматика М. Смотрицького - перлина давнього мовознавства, [в:] Електронний pecypc: http//litopys/org.ua/smotrgram/sm01.htm (12.02.2018).

Німчук В., Систематичний підручник иерковнослов'янської мови „Граматика словенская” Л. Зизанія, [в:] Електронний ресурс: http//litopys/org.ua/smotrgram/sm01.htm (12.02.2018).

Німчук В., Пуряєва Н., Історія українського правопису: XVI-XX століття, хрестоматія, Київ 2004.

Огіснко І., Нариси з історії украйнської мови: система украйнського правопису, Варшава 1927.

Пещак М., Формальні ознаки членування тексту грамот, [в:] Ії̈ ж, Стиль ділових документів XIV cm. (структура тексту), Київ 1979, с. 65-79.

Савченко I., Історичний илях украӥнської пунктуачійної системи, [в:] „Мовознавчий вісник", зб. наук. праць, Черкаси 2011, вип. 12-13, с. 284-291.

Сімович В., Граматика украӥнської мови. Для самонавчання та в допомогу шкільній наyųi, 2-е вид. $з$ одмінами й додатками, Київ-Ляйпціг 1921.

Смаль-Стоцький С., Гартнер Ф., Граматика руської мови, Відень 1914.

Тимченко Є., Украӥнська граматика, Київ 1907. 
Український правопис, Київ 1960.

Украӥнський правопис, Київ 1993.

Чорній С., Граматика украӥнської мови, ч. 2, Синтакса, Брокпорт; Нью-Йорк 1969.

Шевельов Ю., Українська мова в першій половині ХХ cm. (1900-1941): Стан і статус, Чернівці 1993.

Шульжук К., Синтаксис украӥнської мови, Київ 2004.

\section{Spysok vykorystanoi literatury [References]}

Androshchuk N., Formuvannia punktuatsiinoi systemy suchasnoi ukrainskoi movy ta yii vidobrazhennia $v$ pravopysnykh dzherelakh [Formation of the Ukrainian Language Punctuation System and its Reflection Orthography Sources], [v:] „Naukovyi visnyk Skhidnoievropeiskoho natsionalnoho universytetu imeni Lesi Ukrainky. Filolohichni nauky. Movoznavstvo", Lutsk 2013, vyp. 22, s. 3-7.

Bandura O., Khudozhni funktsii poetychnoi punktuatsii [Fiction Functions of Poetic Punctuation], [v:] „Ukrainska mova ta literatura”, 1997, № 46 (62), s. 9-12.

Bulakhovskyi L., Ukrainska punktuatsiia [Ukrainian Punctuation], Kyiv 1947.

Buriachok A., Shcho zminylosia v ,Ukrainskomu pravopysi” [What has Changed in "Ukrainian Spelling”], Kyiv 1997.

Vashchenko V., Hramatyka Meletiia Smotrytskoho [Grammar of Meletiy Smotrytskyi], [v:] „Ukrainska mova v shkoli”, 1957, № 3, s. 27-33.

Vashchenko V., Stylistychne vykorystannia punktuatsii [Stylistic Use of Punctuation], [v:] „Ukrainska mova v shkoli”, 1951, № 5, s. 31-35.

Hrunskyi M., Myronenko M., Rozdilovi znaky [Punctuation Marks], Kharkiv 1930.

Huivaniuk N., Istorychna zminnist punktuatsii ta zminy v ukrainskii punktuatsii [Historical Change of Punctuation and Changes in Ukrainian Punctuation], [v:] Yii zh, Suchasni problemy movoznavstva ta literaturoznavstva, Chernivtsi 2002, vyp. 6, s. 299-305.

Huivaniuk N., Novitni tendentsii v ukrainskii punktuatsii ta problemy avtorskoi punktuatsii. Slovo. Rechennia. Tekst. [Modern Tendencies in Ukrainian Punctuation and Problems of Author's Punctuation], Chernivtsi 2009, s. 486-492.

Zahnitko A., Suchasna ukrainska literaturna mova. Syntaksys prostoho uskladnenoho i skladnoho rechennia [Modern Ukrainian Literary Language. Syntax of Simple and Complex Sentences], Donetsk 1994.

Zahnitko A., Teoretychna hramatyka suchasnoi ukrainskoi movy. Syntaksys [Theoretical Grammar of Modern Ukrainian. Syntax], Donetsk 2000.

Kyslytsia D., Hramatyka ukrainskoi movy [The Ukrainian Language Grammar], ch. 2, Syntaksa, Niu-York 1990.

Kovaliv P., Ukrainskyi pravopys i vymova [Ukrainian Spelling and Pronunciation], Niu-York 1946.

Kovaliv P., Ukrainskyi pravopys i vymova [Ukrainian Spelling and Pronunciation], Niu-York 1977.

Krymskij A., Ukrainskaya grammatika dlya uchenikov vysshih klassov gimnazij i seminarij Pridneprov'ya [Grammar of the Ukrainian Language for Gymnasium Pupils of Pridneprovja], Moskva 1907, t. 2, vyp. 1.

Kurdynovskyi V., Rozdilovi znaky v ukrainskii movi [Punctuation Marks in the Ukrainian Language], Kharkiv 1931.

Mozghova N., Syntaksychni pryntsypy pravopysu ta yoho realizatsiia [Syntactic Principles of Spelling and its Realization], [v:] Elektronnyi resurs: http:www.donduet.edu.ua/docs/ vestnik/2006/Vest_gum_2(30)_2006/SPM/mozgova.doc (14.02.2018).

Moskalenko N., Narys Istorii ukrainskoi punktuatsiinoi terminolohii [Sketches on History of Ukrainian Punctuation Terminology], Odesa 1959.

Neutriievskyi I., Naiholovnishi pravyla punktuatsii v ukrainskii movi. Rozdilovi znaky [Main Punctuation Rules of the Ukrainian Language. Punctuation Marks], Kharkiv 1930. 
Nechui-Levytskyi I., Hramatyka ukrainskoi movy [The Ukrainian Language Grammar], ch. 2, Syntaksys, Kyiv 1914.

Nimchuk V., Hramatyka M. Smotrytskoho - perlyna davnoho movoznavstva [Grammar of M. Smotrytskyi - Pearl of Ancient Linguistics], [v:] Elektronnyi resurs: http//litopys/org. ua/smotrgram/sm01.htm (12.02.2018).

Nimchuk V., Systematychnyi pidruchnyk tserkovnoslovianskoi movy „Hramatyka slovenskaia" L. Zyzaniia [Systematic Textbook of Church Slavic Language "Grammar of Slavic" by " L. Zyzaniia], [v:] Elektronnyi resurs: http//litopys/org.ua/smotrgram/ sm01.htm (12.02.2018).

Nimchuk V., Puriaieva N., Istoriia ukrainskoho pravopysu XVI-XX stolittia [History of Ukrainian Spelling of the XVI-XXth century], khrestomatiia, Kyiv 2004.

Ohiienko I., Narysy z istorii ukrainskoi movy: systema ukrainskoho pravopysu [Sketches on the Ukrainian Language: System of Ukrainian Spelling], Varshava 1927.

Peshchak M., Formalni oznaky chlenuvannia tekstu hramot [Formal Features of Brevet Text Division], [v:] Yoho zh, Styl dilovykh dokumentiv XIV st. (struktura tekstu), Kyiv 1979, s. $65-79$.

Savchenko I., Istorychnyi shliakh ukrainskoi punktuatsiinoi systemy [Historical Way of Ukrainian Punctuation System], [v:] „Movoznavchyi visnyk”, zb. nauk. prats, Cherkasy 2011, vyp. 12-13, s. 284-291.

Simovych V., Hramatyka ukrainskoi movy. Dlia samonavchannia ta $v$ dopomohu shkilnii nautsi [The Ukrainian Language Grammar. For Autonomous Learning and to Help School Science], 2-e vyd. z odminamy y dodatkamy, Kyiv-Liaiptsih 1921.

Smal-Stotskyi S., Hartner F., Hramatyka ruskoi movy [Grammar of Russian Language], Viden 1914.

Tymchenko Ye., Ukrainska hramatyka [The Ukrainian Language Grammar], Kyiv 1907.

Ukrainskyi pravopys [Ukrainian Spelling], Kyiv 1960.

Ukrainskyi pravopys [Ukrainian Spelling], Kyiv 1993.

Chornii S., Hramatyka ukrainskoi movy [The Ukrainian Language Grammar], ch. 2, Syntaksa, Brokport; Niu-York 1969.

Shevelov Yu., Ukrainska mova v pershii polovyni XX st. (1900-1941): Stan i status [The Ukrainian Language in the First Part of the XXth century], Chernivtsi 1993.

Shulzhuk K., Syntaksys ukrainskoi movy [The Ukrainian Language Syntax], Kyiv 2004. 